\section{Improving Underrepresented Minority Student Persistence in STEM}

\author{
Mica Estrada, ${ }^{1 *}$ Myra Burnett, ${ }^{2}$ Andrew G. Campbell, ${ }^{3}$ Patricia B. Campbell, ${ }^{4}$ \\ Wilfred F. Denetclaw, ${ }^{5}$ Carlos G. Gutiérrez, ${ }^{6}$ Sylvia Hurtado, ${ }^{7}$ Gilbert H. John, ${ }^{8}$ \\ John Matsui, ${ }^{9}$ Richard McGee, ${ }^{10}$ Camellia Moses Okpodu, ${ }^{11}$ T. Joan Robinson, ${ }^{12}$ \\ Michael F. Summers, ${ }^{13,14}$ Maggie Werner-Washburne, ${ }^{15}$ and MariaElena Zavala ${ }^{16}$ \\ ${ }^{1}$ Department of Social and Behavioral Sciences, University of California, San Francisco, \\ San Francisco, CA 94118; ${ }^{2}$ Office of the Provost, Spelman College, Atlanta, GA 30314-4399; \\ ${ }^{3}$ Molecular Microbiology \& Immunology, Brown University, Providence, RI 02912; \\ ${ }^{4}$ Campbell-Kibler Associates, Inc., Groton, MA 01450; ${ }^{5}$ Department of Biology, San Francisco \\ State University, San Francisco, CA 94132; ${ }^{\circ}$ Department of Chemistry and Biochemistry, California \\ State University, Los Angeles, Los Angeles, CA 90032-8202; ' $E d u c a t i o n$ Department, University of \\ California, Los Angeles, Los Angeles, CA 90095-1521; ${ }^{8}$ Microbiology and Molecular Genetics, \\ Oklahoma State University, Stillwater, OK 74078; ${ }^{9}$ Biology Scholars Program, University of \\ California, Berkeley, Berkeley, CA 94720-3140; ${ }^{10}$ Faculty Affairs, Feinberg School of Medicine, \\ Northwestern University, Chicago, IL 60611; ${ }^{11}$ Department of Biology, Norfolk State University, \\ Norfolk, VA 23504; ${ }^{12}$ Division of International Affairs, Morgan State University, Baltimore, MD \\ 21251; ${ }^{13}$ Howard Hughes Medical Institute, Chevy Chase, MD 20815; ${ }^{14}$ Chemistry and Biochemistry \\ Department, University of Maryland, Baltimore County, Baltimore, MD 21250; ${ }^{15}$ Department of \\ Biology, University of New Mexico, Albuquerque, NM 87131-0001; ${ }^{16}$ Department of Biology, \\ California State University, Northridge, Northridge, CA 91330-8303
}

\begin{abstract}
Members of the Joint Working Group on Improving Underrepresented Minorities (URMs) Persistence in Science, Technology, Engineering, and Mathematics (STEM)-convened by the National Institute of General Medical Sciences and the Howard Hughes Medical Institute-review current data and propose deliberation about why the academic "pathways" leak more for URM than white or Asian STEM students. They suggest expanding to include a stronger focus on the institutional barriers that need to be removed and the types of interventions that "lift" students' interests, commitment, and ability to persist in STEM fields. Using Kurt Lewin's planned approach to change, the committee describes five recommendations to increase URM persistence in STEM at the undergraduate level. These recommendations capitalize on known successes, recognize the need for accountability, and are framed to facilitate greater progress in the future. The impact of these recommendations rests upon enacting the first recommendation: to track successes and failures at the institutional level and collect data that help explain the existing trends.
\end{abstract}

\section{INTRODUCTION}

The United States' inability to achieve science, technology, engineering, and mathematics (STEM) workforce diversity goals has long been attributed to the failure of the academic "pipeline" to maintain a steady flow of underrepresented minority (URM) students. While there have been some gains, national data continue to show that the disparity in STEM degree attainment for URM students (i.e., African American, Hispanic or Latino/Latina, American Indian, and Alaska Natives) increases at each degree level, compared with white and Asian students (see Figure 1). We propose that deliberation about why the "pipeline" leaks more for URM than white or Asian students should be expanded to include a stronger focus on the institutional barriers that need to be removed and the types of interventions that "lift" students' interests, commitment, and ability to persist in STEM fields.
Pat Marsteller, Monitoring Editor Submitted January 14, 2016; Revised June 1 2016; Accepted June 3, 2016

CBE Life Sci Educ September 1, 2016 15:es5 DOI:10.1187/cbe.16-01-0038

*Address correspondence to: Mica Estrada (mica .estrada@ucsf.edu).

(c) 2016 M. Estrada et al. CBE-Life Sciences Education @ 2016 The American Society for Cell Biology. This article is distributed by The American Society for Cell Biology under license from the author(s). It is available to the public under an Attribution-Noncommercial-Share Alike 3.0 Unported Creative Commons License (http://creativecommons.org/licenses/ by-nc-sa/3.0).

"ASCB $\otimes^{\circ}$ and "The American Society for Cell Biology ${ }^{\circledR}$ " are registered trademarks of The American Society for Cell Biology. 


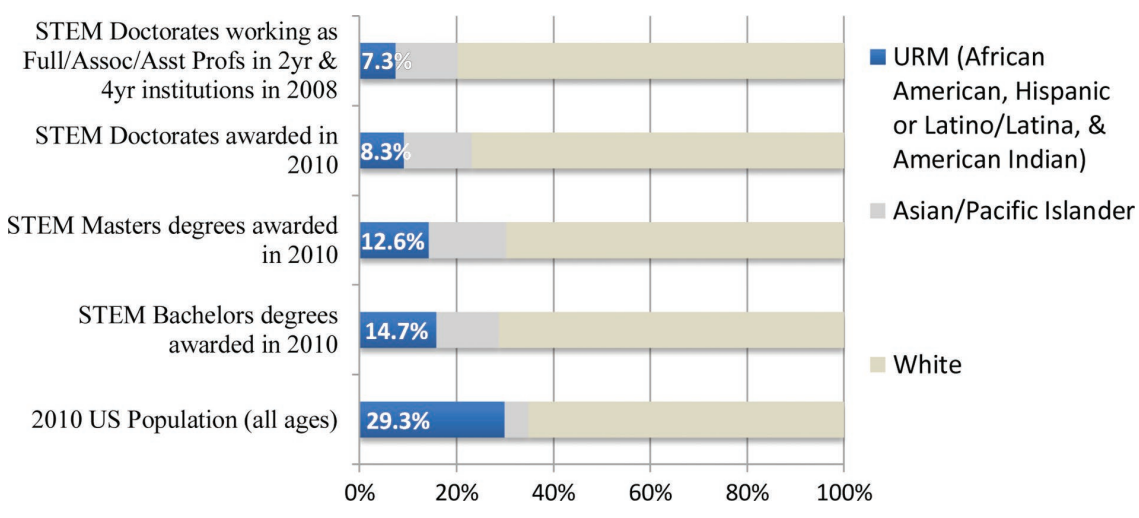

FIGURE 1. Current percentages of underrepresented minority, white and Asian/Pacific Islander populations with STEM degrees. URM includes African American, Hispanic or Latino/Latina, American Indian, and Alaskan Native. In this analysis, "STEM degrees" includes degrees categorized by the NSF as "Science \& Engineering" (but excludes degrees in psychology and social sciences) in data tables prepared by the National Center for Science and Engineering Statistics based on data from the U.S. Department of Education's IPEDS 2010 Completions Survey. Sources: population: U.S. Census Bureau, 2010 Census Summary File 1, tables PCT12H, PCT12I, PCT12J, PCT12K, PCT12L, PCT12M, PCT12N, and PCT120; degrees: NSF, National Center for Science and Engineering Statistics, special tabulations of U.S. Department of Education, National Center for Education Statistics, Integrated Postsecondary Education Data System, Completions Survey, 2001-10; and faculty: National Science Foundation statistics.

As members of the Joint Working Group on Improving URM Persistence in STEM-convened by the National Institute of General Medical Sciences (NIGMS) and the Howard Hughes Medical Institute (HHMI) - our charge was to review current literature and explore barriers to undergraduate URM STEM persistence from a fresh perspective and enable constructive, innovative thinking regarding solutions. The committee was composed of educators with deep experience in addressing URM persistence in STEM, who convened for several multiday formal meetings and sustained ongoing conversations over the course of the past 3 years. Despite committee members' diversity in culture, training, and professional experiences, we strongly converged around the belief that 40 years of intervention experience supported by NIGMS, HHMI, National Science Foundation (NSF), and other funders, coupled with more recent experimental research, has given us sufficient knowledge to address the disparity in STEM fields much more effectively. As a starting point, we address the pervasive pattern wherein URM students plan to undertake STEM majors in college at the same rate as do white students but do not graduate with STEM degrees at that same rate (Hurtado et al., 2009; Presidential Council of Advisors on Science and Technology [PCAST], 2012). The main problem now appears to be that there has not been a national commitment to enact and sustain the institutional initiatives necessary to capitalize on what we know and systematically track successes and failures as we move forward.

\section{Planned Approach to Change}

In the 1940s, Kurt Lewin proposed a now classic planned approach to change involving the concepts of field theory, action research, and a three-step model (Lewin, 1946, 1947). His theory (and method) for change provides a context in which to place the proposed recommendations of the working group. According to field theory, a variety of forces maintain the status quo through contextual and individual inputs such as culture, values, norms, and roles. Change begins by recognizing the fields of influence in a situation and identifying the points at which there are "gatekeepers" that impede the flow of change in a system.

According to Lewin, group, organization, or social system change does not occur by simply shifting individual behavior but requires the larger system to shift as well. Lewin's three-step model, which dominated the field of change management for nearly 40 years and continues to be discussed as relevant (see Burnes, 2004), provides an approach for creating system change. Lewin's model describes the backbone to many change theories (Sarayreh et al., 2013) and shares elements with Elrod and Kezars' (2015) newer, more detailed Keck/PKAL model for institutional change or Austin's (2011) description of how to promote evidence-based change. First, as Lewin describes it, a system or organization must become unfrozen, which can occur from destabilization or from creating awareness that the status quo no longer is functional to achieve the aims of the group, institution, or larger social system (Lewin, 1947). Second, the system experiences moving, which for Lewin involved an iterative process of engaging action research (see Figure 2). Action research classically is a spiral process that operates similarly to how a physician repairs a broken bone and includes the following steps: a) evaluate: collect information about the state of the situation; b) diagnose: use knowledge attained regarding the state of the situation and knowledge of what has worked in the past to identify the gatekeepers (aka barriers) and opportunities to improve the syst em; c) plan: create a plan of action; and then d) take action. After action is taken, return to "a" and reassess the situation-are things better or getting worse? Then one continues through the iterative process of adjusting the plan and implementations until the data show improvement. Importantly, this theory of change cannot occur without good data to inform the progress of change. Finally, when the system is in a new, functional, and perhaps thriving state, step 3, refreezing, occurs, which includes adopting the systems' newer culture, policies, and practices (Cummings and Huse, 1989) and new norms and roles. The classical approach to action research recognizes the expertise of all persons involved in the system and encourages their active contribution to the change process.

With regard to addressing the issue of broadening participation, there was wide agreement that unfreezing (step 1) is occurring because the status quo is clearly not resulting in equity and broadening of the workforce (National Academy of Sciences, National Academy of Engineering, Institute of Medicine, 2007, 2010, 2011; PCAST, 2012; Carnevale and Strohl, 2013; Witham et al., 2015). What follows are recommendations for 




FIGURE 2. Action research model. accountable. To establish institutional benchmarks and encourage greater progress, institutional-level tracking by program of student ethnicity and performance outcomes must begin to occur in a uniform manner, such that comparisons can be made across time, departments, and institutions. What is now opaque can be made visible by systematically tracking the number of degree candidates and earners in STEM disciplines across demographic categories and making those numbers publicly available on institutional websites. In so doing, we 1) enable researchers and practitioners to identify institutions that are making progress (or not) and 2) allow for more careful data-driven analysis of what constitutes effective practices that can be adapted. Federal and private funding agencies should require this information from institutions that receive support in a standardized format that identifies disparity and equity. In addition, annual reports of institutional STEM data could be included in accreditation reviews. Most importantly, colleges and universities themselves stand to benefit from better institu- how to move the system by using an action research methodology, and as Lewin suggests, a key component to this is having data to inform us about the current state of the situation and provide evidence of change (or nonchange) as we move forward. Thus, the first recommendation is focused on acquiring quality information to create accountability. The latter four recommendations describe how to move the system by establishing new practices that shift the culture of science education. The goal is then to refreeze and gain the results that so eloquently describes: "To be stable ... change must, in short, be a change in the 'cultural atmosphere,' not merely a change of a single item" (Lewin, 1943, p. 46).

\section{ESSENTIAL FIRST RECOMMENDATION FOR PROMOTING CHANGE: TRACK AND INCREASE AWARENESS OF INSTITUTIONAL PROGRESS TOWARD DIVERSIFYING STEM}

According to Lewin's theory of change, iterative improvements of a group, system, or institution are greatly facilitated by clearly evaluating the state of the system to assess when change occurs (or not) and inform the diagnosis. Within the field of applied psychology, there is strong evidence that feedback promotes changes in behavior and can increase motivation for attainment of goals, because it creates accountability (Kluger and DeNisi, 1996). Consistent with this orientation, the Joint Working Group strongly recommends that decreasing URM and gender disparity begins with institutional accountability. Currently, there is no requirement for higher education institutions at the undergraduate level to know the ethnic identities of the students who enter, drop, or complete their degree programs. Because of this, such institutions that are successfully narrowing the STEM gap are not always identifiable; nor are institutions that are failing diverse students, perhaps miserably, held tional data on student performance and retention (Burnett, 2006; Hurtado et al., 2009).

In addition to tracking student performance in STEM, institutional data should include time to degree, existing funded and unfunded URM intervention programs at the institution, and participation in research training experiences for URM and non-URM students. These data would considerably enhance educators' and researchers' ability to identify the characteristics of institutions with programs successful at recruiting and retaining URMs. Institutional data would complement current social science findings that show how empowering URMs with the skills, scientific identity, and values of scientists results in students experiencing greater integration into the scientific community and increases the likelihood of their persistence (Hurtado, 2010; Estrada et al., 2011).

Some efforts have begun but are not comprehensive. For example, the National Center for Education Statistics conducts aggregate tracking of persistence in STEM across all colleges and universities in the United States. Their report on undergraduate attrition finds that $48 \%$ of the students who enter college with STEM majors leave those majors before graduation (Chen and Soldier, 2013). According to NCES, African-American students are the most likely ethnic group to leave STEM majors by dropping out of college (29\%) or switching to a non-STEM degree (36\%). There are relatively few reports of institutional-level tracking of STEM performance and persistence and fewer that provide analysis by ethnicity, although the NIH-funded Diversity Program Consortium seeks to track institutional data from multiple institutions from across the United States. Additionally, some institutions have begun internal tracking to understand their programs in relation to persistence and completion in STEM (Mercia 2010; Rask, 2010; Hill et al., 2014), sometimes 
TABLE 1. Summary of recommendations to increase the diversity of undergraduate STEM disciplines

\begin{tabular}{|c|c|c|}
\hline & Recommendations & Possible actions \\
\hline 1 & $\begin{array}{l}\text { Increase institutional } \\
\text { accountability }\end{array}$ & $\begin{array}{l}\text { Establish information systems across institutions that document } 1 \text { ) incoming student interest, 2) declared } \\
\text { major, and 3) department/school/program graduation rates all (1-3) by student ethnicity, gender, } \\
\text { socioeconomic status, and first-generation status. Make this information publicly available and reported to } \\
\text { funding institutions. }\end{array}$ \\
\hline 2 & $\begin{array}{l}\text { Create strategic partnerships } \\
\text { with programs that create } \\
\text { lift }\end{array}$ & $\begin{array}{l}\text { Program directors can begin by identifying the type of program one directs or wishes to direct. Possible } \\
\text { variables to consider: 1) duration of the program, 2) context (i.e., type of university), 3) student type (e.g., } \\
\text { low-, medium-, or high-risk/achievement/potential; culture; socioeconomic status; first-generation status; } \\
\text { motivation), and 4) purpose/goals of the program (short, medium, and long term). Search literature for } \\
\text { publications regarding programs like the one you want to direct. Communicate with funders about their } \\
\text { knowledge of successful programs. Funders can facilitate greatly by supporting collaborations between } \\
\text { successful and new programs. }\end{array}$ \\
\hline 3 & $\begin{array}{l}\text { Unleash the power of the } \\
\text { curriculum }\end{array}$ & $\begin{array}{l}\text { The learning sciences provide many publications that articulate curriculum best practices. Educators can } \\
\text { expand their knowledge about CUREs and other inquiry-based approaches by reading this brief article, } \\
\text { "Inquiry-Based and Research-Based Laboratory Pedagogies in Undergraduate Science" (Weaver et al., } \\
\text { 2008). Alternatively, Anderson et al. (2011) recommend seven institutional shifts that can support } \\
\text { curriculum change in their article "Changing the Culture of Science Education at Research Universities." }\end{array}$ \\
\hline 5 & Fire the creative juices & $\begin{array}{l}\text { For URM students, firing creative juices can occur by linking the work done in their STEM fields to personal } \\
\text { and culturally valued outcomes. Brief but powerful writing exercises can be introduced into classes to help } \\
\text { facilitate this link (see work by Judith Harackiewicz [Harackiewicz et al., 2013] on utility value exercises). } \\
\text { Faculty, departments, and institutions are encouraged to creatively find ways to better connect URM STEM } \\
\text { students to community-based learning opportunities or to find ways to emphasize how classroom content } \\
\text { relates to prosocial communal outcomes. Funding agencies are encouraged to support research in STEM } \\
\text { fields that both advances the fields and explicitly benefits vulnerable communities. }\end{array}$ \\
\hline
\end{tabular}

across multiple institutions. These initiatives share the aim of improving STEM outcomes for students.

\section{FOUR ADDITIONAL RECOMMENDATIONS FOR MOVING THE SYSTEM}

Capitalizing on known successes and working toward greater progress in the future, the Joint Working Group put forth four additional recommendations to increase URM persistence in STEM at the undergraduate level as mechanisms for creating force for change (see Table 1 for summary). However, the impact of these recommendations rests upon the first recommendation to evaluate successes and failures in reducing disparity at the institutional level and collect data that help provide evidence-based intervention choices by using the previously described action research approach to change.

The following recommendations draw on more than 40 years of federal and private funding and tracking of programs aimed at narrowing URM educational achievement gaps (see Table 2 for a list of programs with evidence of long term success). In some cases, these activities helped stimulate broad institutional changes that have led to marked, quantitative improvement in student outcomes, including retention in STEM fields, improvement in academic performance, and matriculation to graduate and professional schools (Okpodu and Maclin, 2009). While local efforts have resulted in some examples of institutional success, effective strategies for moving the system have not permeated the higher education landscape in a broad, lasting manner that might lead to refreezing in an improved state. At this juncture, targeted intervention to improve URM student retention in STEM is both justified and an urgent national priority. In addition to institutional accountability, the committee found strong agreement that there is evidence that the following strategies increase URM persistence at the undergraduate and graduate levels.

\section{Create Strategic Partnerships}

To expand the impact of programs with successful outcomes, strategic partnerships should be formed between accomplished programs such as the ones cited in Table 2 (all of which have reported consistent above-average retention and/or persistence rates across many years) and programs that are (or could be) working with similar student populations. A benefit of strategic partnerships is that programs successful in increasing URM persistence can be modeled or adapted to suit institutional conditions, resources, and existing states of change. This recommendation rests on years of research showing that humans are able to accelerate learning by observing others' successes and failures (Bandura, 1977, 1986). For decades, program directors have been "learning" through a process of trial and error. However, this is no longer necessary. STEM programs that are willing to adapt their approaches can find examples on the higher education landscape of data-driven interventions that impact the individual and create institutional contexts in which students thrive. Commitment to forming strategic partnerships to ignite institutional transformation is an essential factor in improving outcomes for URM STEM students and may be the 
TABLE 2. Types of programs and levels of intervention to increase URM in STEM

\begin{tabular}{|c|c|c|}
\hline & $\begin{array}{l}\text { Highly talented, motivated, and prepared } \\
\text { URM students }\end{array}$ & $\begin{array}{l}\text { Highly talented, motivated, but underprepared } \\
\text { URM students }\end{array}$ \\
\hline $\begin{array}{l}\text { Program } \\
\quad \text { examples }\end{array}$ & $\begin{array}{l}\text { Meyerhoff Scholars, DNIMAS Scholars (Norfolk State } \\
\text { University Dozoretz National Institute for Mathematics } \\
\text { and Applied Sciences) } \\
\text { MARC/U-STAR (NIH-NIGMS Maximizing Access to Research } \\
\text { Careers/Undergraduate Student Training in Academic } \\
\text { Research) } \\
\text { LA-STEM (Louisiana Science, Technology, Engineering \& } \\
\text { Mathematics) Research Scholars }\end{array}$ & $\begin{array}{l}\text { SACNAS/Synapse (Society for Advancement of Chicanos and } \\
\text { Native Americans in Science/Supporting Young Native } \\
\text { Americans to Pursue Science Education) } \\
\text { College Horizons Program, RISE (Research Intensive Senior } \\
\text { Experience) } \\
\text { Biology Scholars Program (UC Berkeley) } \\
\text { IMSD (and NIH-NIGMS Initiative for Maximizing Student } \\
\text { Development) } \\
\text { NIH Women of Color Legacy Project (Spelman) }\end{array}$ \\
\hline $\begin{array}{l}\text { Individual-level } \\
\text { interventions }\end{array}$ & Emphasize elite status as scholar & $\begin{array}{l}\text { Provide pre-freshman summer bridge programs, personalized } \\
\text { academic plans and support, and preresearch training to } \\
\text { prepare students for success. }\end{array}$ \\
\hline & \multicolumn{2}{|c|}{ Build science efficacy, identity as a scientist, and motivation and internalize values of STEM disciplines } \\
\hline
\end{tabular}

most important factor for producing systemic change (Elrod and Kezar, 2015).

To begin the process of forming strategic partnerships, we must identify and understand successful programs, which the committee divided into two categories. As illustrated in Table 2, some successful programs have focused primarily on the highly skilled, prepared, and motivated URM students (Summers and Hrabowski, 2006; Okpodu and Maclin, 2009). Other programs have worked with a broader range of students who have motivation, interest, and talent, but do not enter undergraduate studies well prepared (Matsui et al., 2003). Similar to how a doctor creates a diagnosis based on his or her knowledge or previous experience, diagnosing how to improve a program or institution's persistence rates begins with knowing the attributes of successful programs at a range of institutions, including flagship research universities, liberal arts colleges, and comprehensive state universities.

Current research has started to identify the characteristics of programs that do and do not result in short- and longer-term positive outcomes (Estrada, 2014; Linn et al., 2015). The findings, largely drawn from qualitative and quantitative, theory-driven studies, identify two levels of contribution to program success: individual (person-level) and contextual (institutional/ environmental) interventions. For example, program interventions that support and develop students' science efficacy, identity, motivation, and values have been found to promote persistence (Chang et al., 2011; Chemers et al., 2011; Syed et al., 2011; Hernandez et al., 2012; Graham et al., 2013). One example is Spelman College in Atlanta, Georgia, whose students are URMs in gender and ethnicity, and which has been the top producer of African-American women STEM undergraduates who go on to receive science doctorates since 2008 (National Science Foundation, National Center for Science and Engineering Statistics, 2015a,b). In response to Spelman being identified as a model institution for excellence in undergraduate science and mathematics education, Thompson and Scriven (2008) have documented Spelman's successful approach to STEM education, dating back to 1972, which includes a pre-freshman summer science program, on- and off-campus research experiences for students, and strong faculty mentoring. Encouraging students to realize their academic potential by embracing their ethnic and gender identity has resulted in more than $22 \%$ of graduates obtaining advanced STEM, medical, and allied health degrees (Jackson and Winfield, 2014).

Another example is the University of Maryland-Baltimore County Meyerhoff Scholars Program, which has found success in preparing URM students through a 14-component model that combats factors shown to compromise success in STEM among high-achieving URM students. The Meyerhoff Scholars Program includes elements such as participation in a summer bridge program, building networks of peer support, tutoring, and personal advising (Summers and Hrabowski, 2006; Lee and Harmon, 2013). A key aim of the program is to reduce student isolation and low motivation that may result from unsupportive learning environments. As a consequence of its comprehensive approach, the Meyerhoff Program has produced more than 1000 STEM undergraduates since 1989, 209 of whom have received $\mathrm{PhDs}$, and $70 \%$ of whom are from URM groups.

In contrast to the Meyerhoff Program, the Biology Scholars Program (BSP) at the University of California, Berkeley, has an individualized approach that combines emphasis on reinforcing students' identity as scientists with a supportive and challenging environment of faculty and other mentors committed to student success. BSP selects students based on their passion for science, resilience, persistence, authenticity, willingness to seek and give help, and ability to restrategize and regroup in the face of failure. Traditional measures of success, such as grade point average and Scholastic Aptitude Test scores are not determining factors. BSP reports that, over a 20-year period, their 2080 graduates included 60\% URMS, 70\% women, and 80\% from low-income backgrounds. Across repeated studies, the retention and persistence of BSP students has been shown to be on par with (if not exceeding) rates of high-achieving students (Matsui et al., 2003).

California State University, Los Angeles (Cal State LA), and San Francisco State University (SFSU), both minority-serving and comprehensive state universities, have established very successful training programs to support the development of 
undergraduate and master's students committed to pursuing a PhD (Slovacek et al., 2011; Hernandez et al., 2012). Each program is tailored to its campus, but they share similarities. These institutions identify motivated minority talent and provide programs (Minority Opportunities in Research [MORE] at Cal State LA; Student Research Opportunities Programs [SROP] at SFSU) to develop this talent to a high level through deliberate cocurricular activities that include strong opportunities for research participation; participation in special workshops, seminars, and courses; careful academic and career advisement; and incorporation into the campus scientific community through the interaction with science faculty, academic and industrial scientists, and other successful science students. Emphasis is on student development of solid skills in the sciences, in research, and the English language in preparation for high achievement in demanding PhD programs. The Cal State LA MORE and SFSU SROP programs have together sent hundreds of students to top $\mathrm{PhD}$ programs nationwide, and those students have completed these doctoral programs at rates higher than national averages for all students. NSF has listed both institutions in the top 50 of U.S. institutions whose Hispanic graduates earned science PhDs. Among baccalaureate and master's institutions in the continental United States, Cal State LA is listed as number 1 (National Science Foundation, National Center for Science and Engineering Statistics, 2015a,b).

Each of the programs described focuses largely on student factors to increase persistence and graduation in STEM for talented students who otherwise may have chosen a different pathway through their undergraduate careers. According to Lewin's model of change, such individual variables are important, but insufficient, to produce a widespread improvement in the number of URMs who persist in STEM careers. A second approach of programs successful in increasing URM persistence also aims to change institutional-level variables that may impede student success, such as faculty and institutional expectations, support, departmental diversity, and climate (Anderson et al., 2011; His Horse is Thunder, 2012; Slovacek et al., 2012). Current initiatives have been launched with both the Meyerhoff and BSP programs to promote institutional change. Specifically, the Meyerhoff Program is being embraced and adapted for implementation at two new institutions. BSP, on the other hand, has launched a program designed to broaden its impact across its current institution. Both the Meyerhoff and BSP program expansions entail deepened institutional commitment and model how to develop strategic partnerships.

Unleash the Power of the Curriculum and Active Learning Science education that imbues students not only with scientific factual knowledge but also the ability to use the scientific research process to promote "a lifetime of learning" is strongly needed for all students, but URMs in particular (Anderson et al., 2011). The science curriculum-which includes course content, course sequence, discipline competencies, language, and norms - must also shift to better respond to this new age of technology, information, and rapidly advancing scientific findings. For instance, Mount Sinai School of Medicine developed a postbaccalaureate program of "systematic coaching," an intensive skills-development process to encourage persistence in biomedical careers beyond the undergraduate level (Krulwich, 2009). Several efforts, such as the Partnership in Undergraduate Life
Sciences Education (www.pulsecommunity.org), initiated through a collaborative effort between HHMI, NSF and NIGMS, and the Association of American Universities Undergraduate STEM Education Initiative (https://stemedhub.org/groups/ aau), are advancing collective institutional efforts to implement new models for STEM curricula to respond better to technological and theoretical advances. At the level of single colleges and universities, many successful models exist to inform the efforts of peer institutions.

One of the most dramatic examples of curricular change is Harvey Mudd College located in Claremont, California. With interventions such as a restructured introductory computer science course, early exposure to research, and regular introduction to women computer science professionals, Harvey Mudd quadrupled the number of women in computer science from 10 to $40 \%$ over a 5 -year period (Corbett and Hill, 2015). An important element of its success was to counteract students' feelings of being "imposters" who were not sufficiently capable of achievement in STEM fields. Harvey Mudd also modified its Introduction to Computer Science course to focus on creative problem solving, making it more attractive to students who did not have strong backgrounds in computer programming. Once engaged in the major, students were assigned summer research projects and taken to the Grace Hopper Conference for women in computer science.

Course-based undergraduate research experiences (CUREs) also are emerging as cutting-edge ways to infuse entry-level classes with hands-on research experiences for science students (Auchincloss et al., 2014). While there are a variety of types of CUREs, they hold in common the placement of "authentic" research experiences in the context of undergraduate courses. There is growing evidence that CUREs result in greater retention of interest and persistence in science. Several institutions are now adopting CUREs that have been shown to be efficacious, such as the SEA-PHAGES program developed initially at the University of Pittsburgh or the Freshman Research Initiative (FRI) at the University of Texas, Austin. These types of curricular changes have been shown to impact knowledge acquisition and psychosocial outcomes and persistence for students, (Shear and Simmons, 2011; Brownell et al., 2012; Alkaher and Dolan, 2014; Bangera and Brownell, 2014; Jordan et al., 2014). Exposure to authentic research experiences for URMs during the academic year particularly has been shown to increase persistence (Hurtado et al., 2009; Schultz et al., 2011; Rodenbusch et al., 2016).

\section{Address Student Resource Disparities}

There is strong evidence that URM undergraduate students are more likely than white or Asian students to come from low-income households, be first-generation college students, and experience financial strain while attending college or university (Kuh et al., 2006; Cullinane and Leewater, 2009). Other evidence of financial strain is contained in the 1996 NSF report Women, Minorities, and Persons with Disabilities in Science and Engineering (National Science Foundation, National Center for Science and Engineering Statistics, 2015a), which reports that URM science and engineering students are more likely to come from families in poverty. The lack of financial resources hinders the ability of undergraduates to engage fully in their studies and disproportionately impacts URM students, who are overrepresented in low socioeconomic status categories. Poor students, 
whether enrolled full time or part time, are more likely to work, resulting in less time to study, do internships in research laboratories, participate in STEM organizations, and attend summer STEM preparation programs. The impact of work on academic achievement, particularly work in off-campus locations, has been shown to have a deleterious impact on student performance (Thompson and Scriven, 2008). Institutions that are able to provide student financial support will produce stronger persistence and higher levels of student performance. This systemic element must not be overlooked in the universe of factors that impact the success of URM students in STEM.

We strongly encourage federal and private agencies to provide greater financial resources to low-income STEM students to reduce the significant barriers that impede URMs from fully engaging in the sciences. The inequity, of course, is embedded in the national economic landscape that exists within and beyond academic institutions, which ultimately requires action but is beyond the scope of this paper. Regardless of the source of the economic disparity, it is clear that financial strains can deeply impact URM STEM students' career trajectories. Likewise, there is also strong evidence that, even when financial resources are similar between URM and majority students, URMs are more likely to drop out of science-track educational pursuits (National Research Council, 2005). While addressing the economic disparities is essential, it is not sufficient to bridge the gap completely.

\section{Fire Students' Creative Juices}

When career scientists are informally asked to describe why they do science, quite often they describe how doing science is a creative and meaningful process for them. Current research on the adoption of academic and scientific values, whether stimulated in a classroom, an internship, work, a training program, or mentorship relationship, suggests that URM students are more likely to pursue a science career if they internalize the values of the scientific community-such as believing that it is important to work to discover knowledge using the scientific method or that scientific research can solve many of today's global challenges (Estrada et al., 2011). The value of STEM skills and learning vary from person to person (values are subjective) and influence motivation to persist in an activity. Research in the learning sciences show that a person's value of a task is actually a stronger predictor of task motivation and creativity than expectancies for success (Xiang et al., 2003; Wigfield et al., 2009). This suggests that motivation is more likely to be sustained when the work being done is meaningful and consistent with personal (and perhaps cultural) values. On the basis of this research evidence and experience, we recommend rallying URM students around grand valued challenges of national and global significance-renewable energy, clean water, health, and climate change-that provide long-term positive contributions to society and their ethnic communities. Being invested in the research outcomes is an important factor in increasing enthusiasm for STEM academic achievement and long-term career choices. Also, providing interventions within or outside the classroom that help students connect the learning of science to held values can serve to shift interest in STEM topics.

Judith Harackiewicz's (Harackiewicz et al., 2013) research has provided empirical evidence that connecting course work to a student's values can impact academic success and per- sistence, serving as a means to ignite interest. Specifically, she randomly assigned biology undergraduates to 1) affirm personal values and later to 2) focus on the relevance and utility value of their biology course material (or not). Results showed improved course grades, semester grades, and persistence for first-generation students (relative to continuing-generation students). These results suggest that including activities that connect learning to what students value could potentially impact course selection and persistence in difficult STEM courses. One simple effective intervention, which could easily be incorporated into introductory STEM courses, is to have students write about the relevance of course topics to their own lives (Hulleman and Harackiewicz, 2009; Hulleman et al., 2010). The use of undergraduate research experiences (UREs), which commonly occur outside the classroom, stimulates students' sense of discovery and appears to impact cognitive gains and contribute to greater retention (Laursen et al., 2010; Lopatto and Tobias, 2010). Future research is still needed to verify whether ignited creativity and meaning mediate these outcomes, but anecdotal evidence suggests this hypothesis deserves future study.

There is a plethora of methods for igniting the creative juices of students, but for URM students, it may be particularly important that collectivistic values (common to Latino, Native American, and African-American cultures), which emphasize actions that benefit their communities, are favored over more individualistic cultural values that celebrate individual success and accomplishment (Triandis, 1993). More recent research on communal goals has shown that URM students in STEM more highly endorse communal goals (Smith et al., 2014; Thoman et al., 2015). And there is increasing evidence that URM motivation and persistence in STEM fields must address cultural issues such that the goals of STEM fields are more congruent with student prosocial goals (shaped by their cultural experiences; Allen et al., 2015). Further, research on communal goal affirmation provides empirical evidence that URMs and women are more likely to engage in science for altruistic reasons and in pursuit of valued social causes (Seymour and Hewitt, 1994; Miller et al., 2000). Ultimately, successful STEM professionals are those who find their work satisfies creative needs and adds meaning, which occurs when a student connects scientific discovery with what really matters given their life and cultural experiences.

\section{SUMMARY}

While the members of the NIGMS-HHMI Joint Working Group come from many different disciplines and bring with them a diversity of academic institutional experiences, the committee has wide consensus regarding the recommendations for moving STEM disciplines toward broader participation. Understood within the theoretical framework of Kurt Lewin (1946), the recommendations provide a map for 1 ) how to better evaluate the state of institutions and track progress, resulting in greater institutional accountability; and 2) how to better use existing knowledge and experiences to iteratively diagnose and create a plan of action to move the system through creating strategic partnerships, unleashing the power of the curriculum, addressing student resource disparities, and firing students' creative juices to sustain progress in STEM. For moving the academic system through reducing disparity and capitalizing on the 
strengths of the ethnic diversity of the U.S. population (using an action research approach), two guiding principles are recommended. First, build on what works. All members of the advisory group touted the fact that we have examples of programs that are exceptionally effective at supporting URM persistence in STEM and that the characteristics of those programs that create "lift" for URM STEM students must continue to be systematically identified, empirically tested, and widely applied across science programs nationwide. At this time, successful programs are defined by both national reputation and evidence that the retention and/or persistence rates of students consistently exceed the average for that department, school, university, or nation.

Second, be guided by data, proven theory, and effective practice. Effective programs and approaches will gain the greatest momentum if we can see the amount of progress or disparity that exists at the institutional level, both quantitatively and qualitatively. Likewise, at the program level, successes and failures in specific interventions should continue to be rigorously assessed using behavioral and social science research designs, and refined as needed, based on evidence. Future research on activities that involve program adaptations, curricular reform, reducing economic disparity, and igniting greater "fire" should include the following when possible: 1) comparison groups; 2) prospective, longitudinal tracking of short-, medium-, and long-term impacts; 3) large enough sample sizes to draw statistical conclusions (achieved through collecting similar data across multiple institutions or like programs when possible); and 4) collection of information that both tracks important outcomes (such as retention and persistence) and helps us to understand why these outcomes occurred.

The committee of experts on URM education in STEM fields concluded that, when institutions, science educators, and funders commit to these five recommendations (guided by the two basic principles just described), the system will move positively and significantly toward accomplishing increased equity and better celebrate the successes of institutions that achieve parity. Through innovation and creation of supportive environments that are excellent and inclusive, all students will garner greater lift and thrive.

\section{ACKNOWLEDGMENTS}

The convening of the working group was supported by the HHMI. The authors also want to acknowledge the invaluable contributions from Drs. Cynthia M. Bauerle and Shawn Gaillard to the manuscript-writing process.

\section{REFERENCES}

Alkaher I, Dolan EL (2014). Integrating research into undergraduate courses: current practices and future directions. In: Research in Science Education: Research Based Undergraduate Science Teaching, ed. D Sunal, C Sunal, D Zollman, C Mason, and E Wright, Charlotte, NC: Information Age.

Allen MJ, Muragishi GA, Smith JL, Thoman DB, Brown ER (2015). To grab and hold: cultivating communal goals to overcome cultural and structural barriers in first-generation college student's science interest. Transl Issues Psychol Sci 1, 331-341.

Anderson WA, Banerjee U, Drennan CL, Elgin SCR, Epstein IR, Handelsman J, Hatfull GF, Losick R, O'Dowd DK, Olivera BM, et al. (2011). Changing the culture of science education at research universities. Science 331, 152 153.

Auchincloss LC, Laursen SL, Branchaw JL, Eagan K, Graham M, Hanauer DI, Lawrie G, McLinn CM, Pelaez N, Rowland S, et al. (2014). Assessment of course-based undergraduate research experiences: a meeting report. CBE Life Sci Educ 13, 29-40.

Austin A (2011). Promoting evidence-based change in undergraduate science education, a paper commissioned by the National Academies National Research Council, Board on Science Education. www.tidemarkinstitute .org/sites/default/files/documents/Use\%20of\%20Evidence\%20in\%20 Changinge $\% 20$ Undergraduate $\% 20$ Science $\% 20$ Education $\% 20 \% 28$ Austin\%29.pdf (accessed 26 July 2016).

Bandura A (1977). Social Learning Theory, Englewood Cliffs, NJ: Prentice Hall. Bandura A (1986). Social Foundations of Thought and Action: A Social Cognitive Theory, Englewood Cliffs, NJ: Prentice Hall.

Bangera G, Brownell SE (2014). Course-based undergraduate research experiences can make scientific research more inclusive. CBE Life Sci Educ 13, 602-606.

Brownell SE, Kloser MJ, Fukami T, Shavelson R (2012). Undergraduate biology lab courses: comparing the impact of traditionally base. J Coll Sci Teach 41, 36-45.

Burnes B (2004). Kurt Lewin and the planned approach to change: a re-appraisal. J Manage Stud 41, 977-1002.

Burnett M (2006). Strengthening the effectiveness of minority-serving institutions. DiverseEducation.com, http://diverseeducation.com/article/6615/ (accessed 26 July 2016)

Carnevale AP, Strohl J (2013). Separate and Unequal: How Higher Education Reinforces the Intergenerational Reproduction of White Racial Privilege, Washington, DC: Georgetown Public Policy Institute. https://cew georgetown.edu/wp-content/uploads/2014/11/SeparateUnequal.FR_ .pdf (accessed 28 December 2015).

Chang MJ, Eagan MK, Lin MH, Hurtado S (2011). Considering the impact of racial stigma and science identity: persistence among biomedical and behavioral science students. J High Educ 82, 564-597.

Chemers MM, Zurbringgen EL, Goza BK, Bearman S (2011). The role of efficacy and identity in science career commitment among underrepresented minority students. J Soc Issues 67, 469-491.

Chen X, Soldier M (2013). STEM Attrition: College Students' Paths Into and Out of STEM: Fields Statistical Analysis Report (2013), Washington, DC National Center for Education Statistics. www.nces.ed.gov/pubs2014/ 2014001.rev.pdf (accessed 28 December 2015).

Corbett C, Hill C (2015). Solving the Equation: The Variables for Women's Success in Engineering and Computing, Washington, DC: AAUW. www aauw.org (accessed 29 December 2015).

Cullinane J, Leewater LH (2009). Diversifying the STEM Pipeline: The Model Replication Institutions Program, Washington, DC: Institute for Higher Education Policy. www.ihep.org/sites/default/files/uploads/docs/pubs/ report_diversifying_the_stem_pipeline_report.pdf (accessed 8 January 2016).

Cummings TG, Huse EF (1989). Organization Development and Change, Eagan, MN: West Publishing

Elrod S, Kezar A (2015). Increasing student success in STEM. Peer Review 17(2). www.aacu.org/peerreview/2015/spring/elrod-kezar (accessed 5 January 2016).

Estrada M (2014). Ingredients for improving the culture of STEM degree attainment with co-curricular supports for underrepresented minority students, Commissioned paper for National Academies of Science, Engineering and Medicine. http://sites.nationalacademies.org/cs/groups/ dbassesite/documents/webpage/dbasse_088832.pdf (accessed 26 July 2016).

Estrada M, Woodcock A, Hernandez PR, Schultz PW (2011). Toward a model of social influence that explains minority student integration into the scientific community. J Educ Psychol 103, 206-222.

Graham MJ, Fredrick J, Byars-Winston A, Hunter A, Handelsman J (2013). Increasing persistence of college students in STEM. Science 341, 1455-1456.

Harackiewicz JM, Canning EA, Tibbetts Y, Giffen CJ, Blair SS, Rouse DI, Hyde JS (2013). Closing the social class achievement gap for first-generation students in undergraduate biology. J Educ Psychol 106, 375389 
Hernandez PR, Schultz PW, Estrada M, Woodcock A, Chance RC (2012) Sustaining optimal motivation: a longitudinal analysis of personal and contextual predictors of achievement goals. J Educ Psychol 105, 1-36.

Hill S, Slusaw D, Wisser J (2014). Understanding causes of high attrition rates in STEM majors. http://cese.science.psu.edu/files/ CausesofHighAttritionRatesinSTEMmajors.pdf (accessed 8 December 2015).

His Horse is Thunder D (2012). Breaking Through Initiative: Breaking Through Tribal Colleges and Universities, Alexandria, VA: American Indian Higher Education Consortium. Report used with the permission of the American Indian Higher Education Consortium @AIHEC 2012. All other rights are reserved.

Hulleman CS, Godes O, Hendricks BL, Harackiewicz JM (2010). Enhancing interest and performance with a utility value intervention. J Educ Psychol $102,880-895$

Hulleman CS, Harackiewicz JM (2009). Promoting interest and performance in high school science classes. Science 326, 1410-1412.

Hurtado S (2010). Degrees of Success: Bachelor's Degree Completion Rates among Initial STEM Majors, HERI Research Brief, Los Angeles, CA: Higher Education Research Insitute at UCLA.

Hurtado S, Cabrera NL, Lin MH, Arellano L, Espinosa LL (2009). Diversifying science: underrepresented student experiences in structured research programs. Res High Educ 50, 189-214.

Jackson KM, Winfield LL (2014). Realigning the crooked room: Spelman claims a space for African American women in STEM. Peer Review 16(2). www.aacu.org/peerreview/2014/spring/jackson (accessed 10 January 2016).

Jordan TC, Burnett SH, Carson S, Caruso SM, Clase K, DeJong RJ, Dennehy JJ, Denver DR, Dunbar D, Elgin SCR, et al. (2014). A broadly implementable research course in phage discovery and genomics for firstyear undergraduate students. mBio 5, 1051-13.

Kluger AN, DeNisi A (1996). The effects of feedback on performance: a historical review, a meta-analysis and preliminary feedback intervention theory. Psychol Bull 119, 254-284.

Krulwich TA (2009). A major role for social work input during development of an innovative post-baccalaureate research education program in a medical center environment. Soc Work Health Care 48, 653-664.

Kuh GD, Kinzie J, Buckley JA, Bridges BK, Hayek JC (2006). What Matters to Student Success: A Review of the Literature, Washington, DC: National Postsecondary Education Cooperative, National Center for Education Statistics.

Laursen S, Hunter A-B, Seymour E, Thiry H, Melton G (2010). Undergraduate 647 Research in the Sciences: Engaging Students in Real Science, Hoboken, NJ: Wiley.

Lee DM, Harmon K (2013). The Meyerhoff Scholars Program: changing minds, transforming a campus. Metrop Univ 24, 55-70.

Lewin K (1943). The Special Case of Germany, London: Harper \& Row.

Lewin K (1946). Action Research and Minority Problems, London: Harper \& Row.

Lewin K (1947). Frontiers in Group Dynamics, London: Social Science Paperbacks.

Linn MC, Palmer E, Baranger A, Gerard E, Stone E (2015). Undergraduate research experience: impacts and opportunities. Science 347, 627-633.

Lopatto D, Tobias S (2010). Science in Solution: The Impact of Undergraduate Research on 657 Student Learning, Washington, DC: Council on Undergraduate Research.

Matsui J, Liu R, Kane CM (2003). Evaluating a science diversity program at UC Berkeley: more questions than answers. Cell Biol Educ 2, 117-121.

Mercia J (2010). Better intro courses seen as key to reducing attrition of STEM majors. Science 330, 306

Miller PH, Rosser SV, Benigno JP, Zieseniss M (2000). A desire to help others: goals of high achieving female science undergraduates. Women Stud $Q$ 28(1-2), 128-142.

National Academy of Sciences, National Academy of Engineering, Institute of Medicine (2007). Rising above the Gathering Storm: Energizing and Employing America for a Brighter Economic Future, Washington, DC: National Academies Press. www.nsf.gov/attachments/105652/public/ NAS-Gathering-Storm-11463.pdf (accessed 28 December 2015).
National Academy of Sciences, National Academy of Engineering, Institute of Medicine (2010). Rising above the Gathering Storm, Revisited: Rapidly Approaching Category 5, Washington, DC: National Academies Press. www.nap.edu/catalog/12999/rising-above-the-gathering-storm-revisitedrapidly-approaching-category-5 (accessed 28 December 2015).

National Academy of Sciences, National Academy of Engineering, Institute of Medicine (2011). Expanding Underrepresented Minority Participation: America's Science and Technology Talent at the Crossroads, Washington, DC: National Academies Press. www.nap.edu/catalog/12984/expanding -underrepresented-minority-participation-americas-science-and -technology-talent-at (accessed 10 January 2016).

National Research Council (2005). Assessment of NIH Minority Research Training Programs: Phase 3, Washington, DC: National Academies Press.

National Science Foundation, National Center for Science and Engineering Statistics (2015a). Women, Minorities, and Persons with Disabilities in Science and Engineering. www.nsf.gov/statistics/2015/nsf15311/nsf15311 .pdf (accessed 10 January 2016).

National Science Foundation, National Center for Science and Engineering Statistics (2015b). Top Baccalaureate Institutions of Black Science Doctorate Recipients, by Sex: 2008-12. www.nsf.gov/statistics/2015/nsf15311/ tables/pdf/tab7-12.pdf (accessed 18 December 2015).

Okpodu CM, Maclin AP (2009). Twenty-five years of success: a longitudinal study of a successful STEM program and a pilot project to institutionalize its success. Presented at the Third Annual Conference on Understanding Interventions That Broaden Participation in Research Careers (NSB 1201), held May 7-9, 2009, in Bethesda, MD.

President's Council of Advisors on Science and Technology (2012). Engage to Excel: Producing One Million Additional College Graduates with Degrees in Science, Technology, Engineering and Mathematics, Washington, DC: U.S. Government Office of Science and Technology.

Rask K (2010). Attrition in STEM Fields at a Liberal Arts College: The Importance of Grades and Pre-Collegiate Preferences, Ithaca, NY: Cornell Higher Education Research Institute, Cornell University. http://digitalcommons.ilr .cornell.edu/cgi/viewcontent. cgi?article $=1141 \&$ context=workingpapers (accessed 10 January 2016)

Rodenbusch S, Hernandez PR, Dolan EL (2016). Early engagement in coursebased research increases graduation rates and completion of science, engineering, and mathematics degrees. CBE Life Sci Educ 15, ar20.

Sarayreh BH, Khudair H, Barakat EA (2013). Comparative study: the Kurt Lewin of change management. Int J Comput Inf Technol 2, 626629.

Schultz PW, Hernandez PR, Woodcock A, Estrada M, Chance RC, Aguilar M, Serpe RT (2011). Patching the pipeline: reducing educational disparities in the sciences through minority training programs. Educ Eval Policy Anal 33, 95-114.

Seymour E, Hewitt N (1994). Talking about Leaving: Factors Contributing to High Attrition Rates among Science, Mathematics, and Engineering Undergraduate Majors, Boulder, CO: Ethnography and Assessment Research, Bureau of Sociological Research.

Shear RI, Simmons SL (2011). Teaching through research: five-year outcome data from the Freshman Research Initiative at The University of Texas at Austin. Presented at the American Chemical Society 67th Southwest Regional Meeting, held 11 November 2011, in Austin, TX.

Slovacek SP, Whittinghill JC, Flenoury L, Wiseman D (2012). Promoting minority success in the sciences. J Res Sci Teach 49, 199-217.

Slovacek SP, Whittinghill JC, Tucker S, Rath KA, Peterfreund PR, Keuhn GD, Reinke YG (2011). Minority students severely underrepresented in science, technology engineering and math. J STEM Educ 12, 5-16.

Smith JL, Cech E, Metz A, Huntoon M, Moyer C (2014). Giving back or giving up: Native American student experiences in science and engineering Cult Divers Ethnic Minor Psychol 20, 413-429.

Summers MF, Hrabowski FA III (2006). Preparing minority scientists and engineers. Science 31, 1870-1871

Syed M, Azmitia M, Cooper CR (2011). Identity and academic success among underrepresented ethnic minorities: an interdisciplinary review and integration. J Soc Issues 67, 442-468.

Thoman DB, Brown ER, Mason AZ, Harmsen AG, Smith JL (2015). The role of altruistic values in motivating underrepresented minority students for biomedicine. BioScience 65, 183-188. 
Thompson AN, Scriven OA (2008). African American Women in Science: Spelman College as a National Model for Baccalaureate Degree Production in Models for Success: Successful Academic Models for Increasing the Pipeline of Black and Hispanic Students in STEM Areas, 3rd ed. Brooklyn, NY: Thurgood Marshall College Fund.

Triandis H (1993). Collectivism and individualism as cultural syndrome Cross-Cult Res 27, 155-180.

Weaver GC, Russell CB, Wink DJ (2008). Inquiry-based and research-based laboratory pedagogies in undergraduate science. Nat Chem Biol 4, 577580.
Wigfield A, Tonks S, Klauda SL (2009). Expectancy-value theory. In: Handbook of Motivation in School, ed. KR Wentzel and A Wigfield, New York: Routledge, 55-76.

Witham K, Malcom-Piqueux LE, Dowd AC, Bensimon EM (2015). America's Unmet Promise: The Imperative for Equity in Higher Education Washington, DC: Association of American Colleges and Universities. https://secure.aacu.org/store/detail.aspx?id=GMSAUM (accessed 28 December 2015).

Xiang P, McBride R, Guan J, Solmon M (2003). Children's motivation in elementary physical education: an expectancy-value model of achievement choice. Res Q Exerc Sport 74, 25-35. 